\title{
The institutional configuration of sport policy in Brazil: organization, evolution and dilemmas
}

\author{
Alessandra Mendes \\ Federal University of Parana State (UFPR) / Postgraduate Program of Public Policy \\ Curitiba / PR - Brazil \\ Adriano Codato \\ Federal University of Parana State (UFPR) / Department of Political Science \\ Curitiba / PR - Brazil
}

\begin{abstract}
Brazil has become the center of the spotlight of the whole world recently, amongst many other reasons, one of them was because it was chosen to host a series of mega sporting events - Pan American Games in 2007, Confederations Football Cup in 2013, Fifa Football World Cup 2014 Games and 2016 Olympic and Paralympic Games in 2016. However, little is known about the country's administrative governmental structure focused on sport policy. The available studies focus their analysis on the sport policies content, but not on the arrangement of its structural decision-making. The main aim of this article is indeed to describe, based on official documentation, the evolution and the current arrangements of the government responsible for the administrative structure for the planning and implementation of sports policies in Brazil. Thus, we tried to list the main problems arising from the organization of the Brazilian sports' management. These problems are: (1) inappropriate institutional structure in terms of human resources and obstacles to participation by other social actors beyond the officials (parliament and members of the Ministry of Sports) in the sports policy; (2) disarticulation between public institutions generating redundancies and conflicts of jurisdiction due to the poor division of labor between bureaucracy agencies; and (3) inadequate planning proved by the lack of organization of some institutions, and by the lack of assessment and continuity of public policies over time. Therefore, we must emphasize those problems from above, and due to these administrative arrangements, Brazilian sports' policy has big challenges in the sport development in this country, which includes the creation of a national "system" for sports and a priority investment in sport education.
\end{abstract}

KEYWORDs: Brazil; public management; public policy; sport policy; political institutions.

DOI: http://dx.doi.org/10.1590/0034-7612125903

(cc) BY-NC

Article submitted on 31 Oct. 2013 and accepted for publication on 6 Oct. 2014.

Rev. Adm. Pública - Rio de Janeiro 49(3):563-593, maio/jun. 2015 
A configuração institucional da política de esporte no Brasil: organização, evolução e dilemas O Brasil tornou-se foco de atenção mundial nos últimos anos entre outros motivos porque foi escolhido para sediar uma série de megaeventos esportivos — Jogos Pan-americanos em 2007, Copa das Confederações de Futebol em 2013, Copa do Mundo de Futebol em 2014, Jogos Olímpicos em 2016 e Jogos Paraolímpicos em 2016. Contudo, pouco se conhece sobre a estrutura administrativa governamental do país voltada à política de esporte. Os trabalhos disponíveis focam suas análises no conteúdo da política esportiva, mas não no arranjo da sua estrutura decisória. O objetivo deste artigo é descrever, com base na documentação oficial, a evolução e o arranjo atual da estrutura administrativa de governo responsável pela formulação e pela implementação da política de esporte no Brasil. A partir disso, procuramos elencar os principais problemas decorrentes da organização da gestão esportiva brasileira. São eles: (1) estrutura institucional inadequada em termos de recursos humanos e impedimentos à participação de outros atores sociais além dos oficiais (parlamentares e membros do Ministério do Esporte) na política esportiva; (2) desarticulação entre as instituições públicas gerando redundâncias e conflitos de competência em função da má divisão de trabalho entre as agências burocráticas; e (3) planejamento inadequado constatado pela falta de organização de algumas instituições, pela falta de avaliação e de continuidade das políticas públicas ao longo do tempo. Como conclusão, destacamos que, em função desse arranjo administrativo, a política esportiva brasileira tem grandes desafios no desenvolvimento do esporte brasileiro, o que inclui a formação de um "sistema" esportivo nacional e um investimento prioritário no esporte educacional.

Palavras-chave: Brasil; gestão pública; política pública; política de esporte; instituições políticas.

La configuración institucional de la política de deporte en Brasil: organización, evolución y dilemas Brasil se convirtió en el foco de la atención mundial en los últimos años, entre otras razones porque fue elegido como sede de una serie de grandes eventos deportivos - Juegos Panamericanos en 2007, Copa de las Confederaciones de Fútbol en el 2013, Copa Mundial de Fútbol en 2014, Juegos Olímpicos en 2016 y Juegos Paralímpicos en 2016 - , sin embargo, poco se sabe acerca de la estructura administrativa del gobierno del país centrada en la política deportiva. Los estudios disponibles centran sus análisis en el contenido de la política deportiva, pero no en la disposición de su estructura de toma de decisiones. El propósito de este artículo es describir, con base en la documentación oficial, la evolución y la disposición actual de la estructura administrativa del gobierno responsable de la formulación e implementación de la política deportiva en Brasil. De esto, tratamos de enumerar los principales problemas derivados de la organización de la gestión del deporte brasileño. Ellos son: (1) insuficiente estructura institucional en términos de recursos humanos y los obstáculos a la participación de otros actores sociales más allá de oficial (el parlamento y miembros del Ministerio de Deportes) en la política deportiva; (2) desarticulación entre las instituciones públicas que generan redundancias y conflictos de competencia debido a la mala división del trabajo entre los organismos burocráticos; y (3) la planificación inadecuada evidenciada por la falta de organización de algunas instituciones, la falta de evaluación y continuidad de las políticas públicas a través del tiempo. En conclusión, podemos destacar que, debido a este acuerdo administrativo, la política deportiva de Brasil tiene grandes desafíos en el desarrollo del deporte brasileño, que incluye la formación de un "sistema" deporte nacional y una inversión prioritaria en el deporto escolar, como establece la constitución del país.

Palabras clave: Brasil; gestión pública; políticas públicas; política deportiva; instituciones políticas. 


\section{Introduction'}

Brazil has become a focus of world attention in recent years. One reason for this, aside from the economic performance and success of social policies against poverty (Souza and Osório, 2013; Rasella et al., 2013), is that the country became the seat of mega sporting events - Pan American Games in 2007, Confederations Football Cup in 2013, the World Cup in 2014 and Olympic and Paralympic Games in 2016.

However, little is known about the Brazilian government administrative structure geared specifically to the sports policy - in fact, there are few studies on the state administration (Figueiredo, 2010; Burgos and Telles, 2014;). The sport ${ }^{2}$ in Brazil was established by the Law no 630 of 1851, but only in 1916 the State established in its bureaucratic structure a special institution for the implementation of sport policy. This agency has undergone a number of changes since then, demonstrating the difficulty on coordination of actors and interests, coordination of actions, resource allocation and effectiveness of the State to administer this policy.

The aim of this article is to describe the many political institutions responsible for the formulation and implementation of sport policy in Brazil throughout the 20th century and the 21st century. Although there are studies of this type for other countries (Dousti et al., 2013; Bergsgard et al., 2007; Green and Houlihan, 2008; Chalip et al., 1996), there isn't on literature a characterization about how was born, how it evolved, how it is structured today the management of the Brazilian sport policy and the consequences of this structure to the public management of this issue. Usual analysis of sport policy in Brazil focuses practically only the outputs (policies) and are concerned only with the ideological assessment of existing policies or a meta-theoretical discussion about public policy for sport (Castro et al., 2012; Mezzadri and Silva, 2014). Furthermore, these studies still ignore precursor works in the area (DaCosta 1996; Mendes, 2013; Mendes and Codato 2014).

Interests us, above all, to present how these institutions are arranged in the federal organogram and how they interact, highlight the problems arising from this mode of organization. Considering public policies as much a product of the conflict of interests, as the product of a peculiar arrangement of institutions that to manage and channel these interests, this article fits into the theme of the Public Policies for Sport (PPS) focusing on the institutions that produce the PPS in Brazil, which will call political institutions of sport (PIS). The questions that we intend to answer are: i) what are the agencies that administered in the past and today manage the sport policy in Brazil?; ii) what were and what are their goals?; iii) how the PIS were structured and how they have changed over time?; iv) who are its managers and/ or policy-makers? This mapping of the institutional organization is a first step towards more detailed analyzes about the political and bureaucratic disputes over PPS.

\footnotetext{
${ }^{1}$ This study is part of a Ph.D research Alessandra Mendes in development entitled "Management of sport policy: a comparative analysis of Political Institutions".

${ }^{2}$ In the Law no 630/1851 we have the name "gimnastic" but it is a synomn to synonym or a precursor of what was to be the physical education and its contents, the sport.
} 
We start from a general characterization of the mode of organization and operation of the Brazilian state originally developed to understand the decision-making structure of economic policy: this state is not organized as a system coherent and concatenated of norms, procedures and institutions, but the entropic way (Martins, 1985). Therefore, although the "large" (i.e., composed of many agencies, departments and administrative offices, such as the analysis of sport policy will prove) it is, in many areas, "weak" (i.e., unable to exercise adequate regulation or promote a public policy effectively). Result of a state system (dis)ordered this way a series of bureaucratic perversions: institutional evolution and transformation of the state apparatus without a recognizable or pre-established plan, decision-making chains little or nothing structured, duplication of functions between rival institutions, conflicts of responsibilities between different managers of the same polices. An institutional context such as this there is low capacity for planning and implementation of effective public policy. Government institutions responsible for sport policy in Brazil illustrate how these problems can reach the maximum. The amount of abbreviations, the incessant creation of promotion and management of PIS, the constant changes of names of the same organs without major change of its power or function are a testament to a way of management more trial and error than guided by somehow hidden rationality. But are, above all, the most perfect example of failed attempts, over a century to bring order in an area that aroused, until the 1990s, with little effective state interest and that currently seems to have aroused much interest, on the basis of private businesses involved therein, that escapes the possibility of democratic regulation by the same State.

This article is based on documentary research. We mobilize a diverse set of legal documents, official sites, beyond the few references on the specific issue and order information, first chronologically in order to establish the evolutionary line of the institutional system of PIS in Brazil; and descriptively, to present a synthetic picture, but the detailed PIS today.

In the first section we summarize the theoretical assumptions of our approach. In the second section we make a quick review of the scientific literature in the area of PPS in Brazil. In the third section we present how the sport is embedded in the legal regulations of the country, as this regiment culminated in the creation of the PIS; then describe the origin, purpose and legal transformation over time of those intended for political institutions of sport. In the last section we discuss the current design of the PIS to reflect on your chances of effective management of sport policy.

\section{Politics, institutions and political institutions}

The analysis of both politics and policy is conditioned, among other factors, the adequate perception of the importance of formal institutions, legal frameworks, organizational routines, structures of government and its active role on decisions politic [political outcomes]. The basic assumption of this institutionalist view is quite simple: "most political actions of some 
importance occurs within institutions; so it is crucial to understand how they act and how these devices influence the behavior of individuals who work within it" (Peters, 2003:219-220).

"Institutions" may simply designate formal institutions (or "organizations") or informal institutions, for example, bureaucratic procedures, governmental structures, state apparatus and constitutional norms (Ikenberry, 1988). Once constituted, they will have decisive impact on the behavior of agents embedded in the political system (legislators, voters, government officials, interest groups and pressure groups, etc.), determining public policy (Krasner, 1984). But "institutions" are not only the formal elements of the state, while also covering them, of course. Institution designates, in fact, the drawing or institutional configuration that defines and guides the political relations between units of government, its occupants and the political world. It is in this sense that "institution" is used in this article.

Institutional factors are particularly important since it can model preferences, goals and interests of political agents and social agents. These factors unevenly distribute the influences of each type of agent on a particular decision-making process, establishing, from there, a certain hierarchy between those who hold power (Hall, 1986:19).

In summary, institutions structures the (action and the relationship) policy. Not it is, in that sense, just a "context", a place or a landscape where government actions are developed. On the contrary: are own institutions that should, for to be more understood, be contained within the socio-historical context (Steinmo et al., 1992). Hence the need to pay attention for two things: (1) the institutional drawing that regulates a certain type of policy varies in time and space; and (2) there is not a ideal institutional drawing that can be transplanted from one place to another.

Part of this approach further investigate the asymmetric distribution of political resources and meditate on relations of conflicting power among actors involved in specific public policy (legislators, voters, government officials, interest groups and groups of pressure, etc.), seeing the institutions of government not as neutral elements where the political game is played, but as "derivatives products of the struggle between unequal actors" (Steinmo, 2001:365).

As these theoretical assumptions, analyzes and interpretations should therefore focus not only on specific institutions, but causal processes operating in an institutional level. Institutional settings (rather than single institutions) can explain both the institutional arrangements themselves, as the political outcomes from it. Hence the need to think about the whole - the institutional design - to decipher the function of each part isolated (each specific agency). It is then to explain how a set of inter-related institutions are able to shape processes, events, decisions etc. It is doubtful that the inspection of an isolated institution for itself determine institutional effects. The interaction between institutions is that it produces effective consequences. Hence the need, in order to understand the public policy of the sport, know the institutional configuration that manages this public policy. And how it can become a source for its misfits. 


\section{Studies on public policy for sport in Brazil}

When we talk about PPS in Brazil, it is important to demarcate what is the current place of sport in the Brazilian legal regulations. With the establishment of the modern state in many countries, not only the sport became part of the legal framework, but was constitutionalized, Switzerland having been the first country to do so in 1874 and Brazil is the 13th in 1988 (Bueno, 2008). In 1988, the sport was inserted in the Constitution of the Federative Republic of Brazil (CF/1988) as a "social right", i.e., a right of all Brazilians.

The first study that linked Sport and Public Policy in Brazil was by Castellani Filho ${ }^{3}$ in 1985 (Castellani Filho, 1985). In a review of studies on PPS in Brazil, Castro and partners (2012) concluded by the predominance of work on qualitative nature, with evaluation of specific policies (programs and projects) but have a great lack of clarity regarding the methodological aspects of research conducted. A review of Sousa, Silva and Silva (2012) about studies in Brazilian PPS pointed not only the difficulty in identifying the methodology employed in research, but also the excessive concentration on "analysis" and "evaluation" of policies note that what the author calls "analysis" and "evaluation" are really political and ideological judgments of subjective character of policies and not analysis / evaluation of public policy in terms of management. Other equally important issues such as pressure groups, change of agenda, decision-making process itself, and the management structure of the sport received little or no attention from researchers. The issue of management, for example, only appears in just over $8 \%$ of researches (Sousa, Silva and Silva, 2013). Only recently have emerged more studies on other aspects of PPS as the works of Almeida and Marchi Jr. (2011) e Almeida and partners (2012) on financing of sport, for example, and about the lack of evaluation (Starepravo, 2011:254).

As already insisted in section 1 of this article, the institutional setting of the PIS, the form as organize themselves internally and its relations with other government institutions shape the decisions of PPS. However, there are few studies that address the decision-making process and the role of management in PIS. There are currently two available research. A is the area of Administration (Lorenzo, 2008) and another in the area of Political Science (Bueno, 2008). Lorenzo studied the National Sport Council and Bueno assembled a historical overview of the legislation and institutionalization of the sport in Brazil, addressing decision -making process from an analysis of coalition (advocacy coalition framework) of the political forces that determined this legislation and the current institutionalization of PIS as well as the allocation of federal budget to the sport and the allocation of this funding.

Studies like these show that knowledge about the structure and the functioning of PIS in Brazil allows us to think the government difficulties in dealing with management of sport policy.

\footnotetext{
${ }^{3}$ Lino Castellani Filho was National Secretary of the Ministry of Sport and Tourism between 2003 and 2007 — as it was called at that time.
} 


\section{The institutions that produce and manage the sport polity for sport in Brazil}

In Brazil the PIS can be divided into legislative and executive types. Ideally, some PIS produce the PPS, while others would perform the PPS, according to the traditional division of powers, although the latter may also propose policies. This is the first inadequacy of Brazilian public system: lack of clear boundaries between institutions and fluidity in attributions, so that not infrequently produce conflicts of competence between the actors on the institutional roles of "their" offices. The following will be present the legislative and executive PIS.

\subsection{Institutions in of the Federal Legislative Branch: formal (Parliament's Committee) and informal (Parliamentary Front)}

In the Legislature, the PIS are in Congress ${ }^{4}$ and are divided into two types, formal PIS (Parliament's Committee) and informal PIS (Parliamentary Front).

Parliament's Committee are permanent or temporary bodies of specialized technical legislation, that integrate the institutional structure of each chamber of Congress - Chamber of Deputies and Senate - co-participants and agents of the legislative process, whose purpose is to consider and resolve about propositions submitted to its examination, and exercise budgetary oversight and monitoring of plans and programs by the Federal government under specific political issues. Parliament's Committee are formed by senators and deputies elected by citizens and nominees of their respective parties to form committees, which have advice on topics discussed, provided by legislative councilors. These advisers need only have higher educational level, but not necessarily in the area of consulting in which they operate. Thus, a consultant on sport policy can be graduated in law or journalism, for example.

Parliament's Committee include topics of interest to society, and its historical evolution reflects too the history of public policy debates conducted by parliamentarians and representatives of civil society organizations. The emergence of these committees occurs in Brazil from 1823 with the installation of the General Constituent and Legislative Assembly of the Empire of Brazil. Throughout the operation of the National Congress, there were constant updates, including the concerning on permanent comissions, aiming to follow the

\footnotetext{
${ }^{4}$ Constitutional organ which exercises, at the federal level, the functions of the Legislative Branch, namely, drafting laws and supervising the Executive Power/President (his two typical functions), but can be to execute administer and adjudicate (atypical features). The National Congress is bicameral, consisting of two houses: the Senate, composed by 81 senators, representing the 27 Federative Units (26 states and the Federal District), and the Chamber of Deputies, composed by 513 deputies, representing the people. In the Senate, all states (and the Federal District) have the same number of representatives (three senators), regardless of the size of their populations; already in the Chamber of Deputies, the number of representatives, for each state, varies according to the size of its population (more populous states, such as São Paulo, arriving to elect 70 deputies, while the smaller, such as Acre, elect 8). The bicameral system was adopted due to the form of state installed in the country (federalism), seeking to balance the political weight of the Federal Units. For more information about the Congress and its operation, see Ferri and Valle (2006).
} 
changes in Brazilian society. Only in the Chamber of Deputies, has the record that there were 129 permanent comissions over 176 years (1823-2004) (Brusco, 2006). Currently, in 2014, we have 22 permanent comissions in the Chamber of Deputies and 11 permanent comissions in the Senate.

In each chamber of the Congress there is a PIS established as permanent comission as shown in Figure 1. In the Chamber of Deputies it is designated as a Committee on Sport and in the Federal Senate it is the Committee on Education, Culture and Sport.

The Parliamentary Front are suprapartisan associations, of free association by deputies and senators, aimed at improving the legislation on a particular topic, exerting a kind of "internal lobby" (Sena, 2007:2). The Parliamentary Front are informal regimentation because not listed in bylaws of the Chamber of Deputies and the Federal Senate, a statute that disciplines its functioning (Parreira, 2012:37).

Regarding the origin of the Parliamentary Front, Sena (2007:3) record at 1945-64 the existence of the Nationalist Parliamentary Front and, later, during the work of the National Constituent Assembly, the figure of the block called "Centrão". Parreira (2012:40-41) presents data from the 2003 of the Chamber of Deputies's electronic site, which had a record of 50 Parliamentary Fronts in this chamber. Despite these references to the existence of Parliamentary Fronts in National Congress since 1945 they were recognized by Congress only in 2005 when the Act № 69/2005 of the Bureau Director of the Chamber of Deputies determined the formal record of Parliamentary Front in this chamber. There is no a Record like this in the Senate.

According to Act № 69/2005 of the Bureau Director of the Chamber of Deputies, for to do the registration of a Parliamentary Front you need to gather signatures from one third of the members of Congress or the same number of deputies. The Parliamentary Front must be reinstalled every new legislature - procedure also adopted to the special committees and commissions of inquiry, which is justified by the fact that some lawmakers do not be reelect, altering the first requirement. Each Parliamentary Front appoint a representative who shall be responsible in front of the Chamber of Deputies for all information that provide for the Bureau Director. The Parliamentary Fronts registered may require the use of physical space of the Chamber of Deputies for the meetings, provided they do not interfere in the activities of the chamber and does not involve the hiring of personnel or supply of airline tickets - yet this request is subject to the approval of Bureau Director. In other words, the activities promoted by the Parliamentary Front cannot generate expenses for the Chamber. The Act no 69/2005 also ensures that the activities of Parliamentary Front can be recorded and disseminated widely by TV, Radio, Website and Journal of Chamber of Deputies (Câmara dos Deputados, 2005a; Câmara dos Deputados, 2005b).

The Parliamentary Fronts are commonly confused with "Parliamentary Bench", in an automatic relation that the Parliamentary Front formalized the "Parliamentary Bench", because there came to be a public record of its members, which allows that were studies about these regimentation with an easier methodology (Coradini, 2010; Parreira, 2012; Silva, 2013; Vigna, 2007; Vogel, 2005). However, we know that the "Bench" is not the same 
as Parliamentary Front, because the Parliamentary Front has a set number of members and a public identification of its members with the causes they defend, while the "Bench" as interest group that is, has a varied and often limited number of members, an informality which causes that studies on it are made based on inferences about who are its members (Rodrigues, 2009; Silva Jr. et al., 2003; Parreira, 2012; Gomes, 2011; Sena, 2007; Alcoforado, 2010:41; Wolf, 2008:78). Meanwhile, we should also consider that the "Bench" is conceptualized from its operations, ie, it is a nonpartisan body that has a shaped like the top of a group organization because its members respects certain regulations, has a certain bureaucracy, and votes mostly follows the indication of Chief Whip, submitting therefore only the fidelity of their interests (Vigna, 2001:1), developing strategies for occupying the most number of political spaces as possible, because the strength of the group is not just the absolute number of its members but on their ability to mobilize diverse groups, parties and other "Benchs", plus its federal political representation (Vigna, 2007:5). The "Benchs" were informally created during the National Constituent Assembly, which drafted the Constitution of 1988, with the purpose of inserting in the Constitution provisions that would meet the interests of specific groups (Sena, 2007).

As the record of Parliamentary Fronts occurs only in the Chamber of Deputies, only in her are the Legislative PIS, composed of deputies and senators, they are: the Parliamentary Front of Physical Activity for Human Development and Parliamentary Front on Sport, both described in figure 1.

\section{Figure 1 \\ Organization Chart of the current legislative PIS in Brazil}

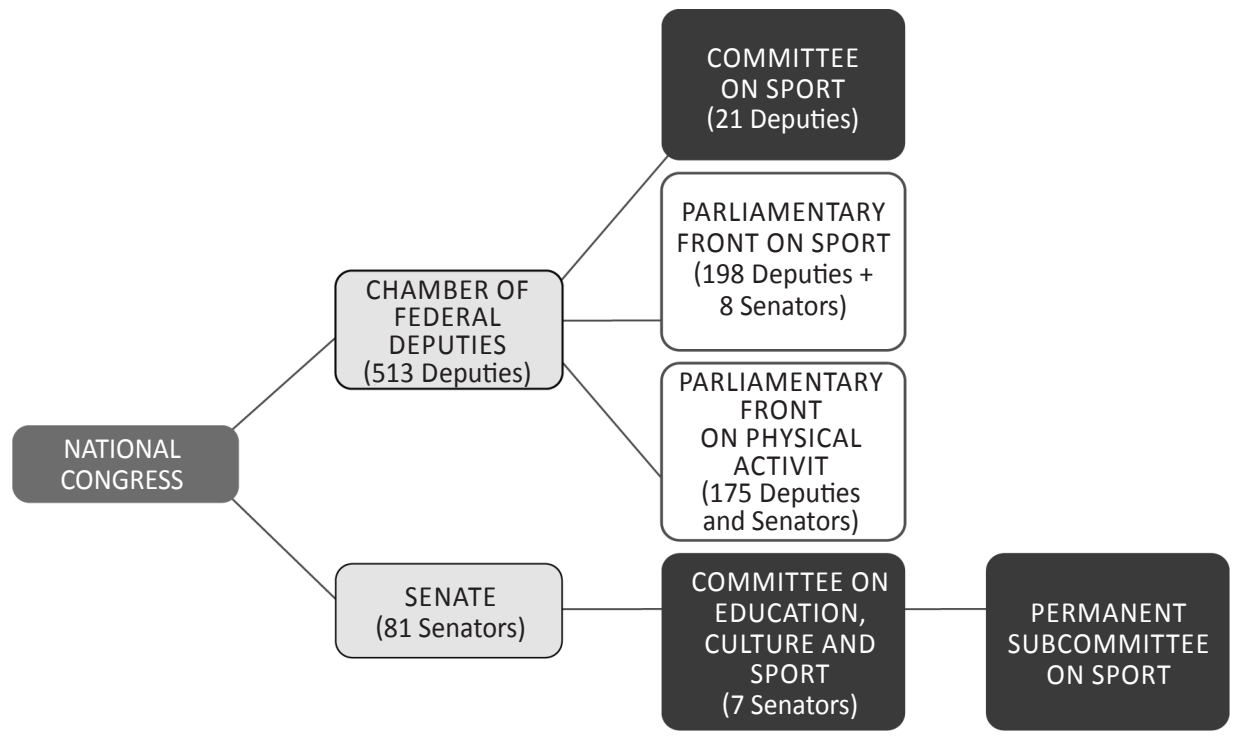

Source: Own elaboration based on data from the National Congress in 2014. 


\subsubsection{The Committee on Sport of the Chamber of Deputies}

Brusco (2006) shows the history of the permanent committees of the Chamber of Deputies since its establishment of the National Congress in 1823 until 2004, in which he notes that the theme of sport was present only from 1983.

Initially called Committee of Sports and Tourism (1983), later with other names such as the Committee on Education, Culture and Sport (1989), Committee on Education, Culture, Sports and Tourism (1989), Commission for Tourism and Sport (2003), current name is Committee on Sport (2014). Among the assignments that had since its creation can be listed as follows: take care of the national sports system and its organization; develop a national policy and national plan of physical education and sport; develop general rules about sport; establish the sport justice; offer prospects of equipping and improvement of the sport; participate as observers in all sporting events deemed of interest. His current assignment is: take care of the national sports system and its organization; develop a national policy and national plan of physical education and sport; develop general rules about sport; establish the sport justice. The Committee on Sport is composed of 21 deputies holders and 21 deputies alternates, but in this moment has 3 places not occupied by alternates. ${ }^{5}$

The Committee on Sport has a page on the website of the Chamber of Deputies where he put his reports, composition, among other information ${ }^{6}$ - up more fully to the Committee on Education, Culture and Sports of the Senate. In the Committee on Sport's website you can see the history of the committee, its assignments, members, sub-committees, law bills and other proposals in progress, terms of amendments, reports, meetings, public hearings, seminars and other events, documents, news, besides being able to contact the commission. There you can observe its political exchange with the executive branch. The first public hearing in 2013, of then called Committee for Tourism and Sport, occurred on April 9 and brought to the plenary the Sport Minister Aldo Rebelo, who presented the plans and programs of your folder for that season, at which the minister suggested to the Committee to submit for the Ministry of Sport a proposal for the National Plan for Sport, provided in the Law № 9.615/1998, whose writing foresaw from 2011 that must prepare a ten-year plan for the sport as assigning of the Ministry of Sport and National Sport Council. However, later there wasn't news about it.

The Confederations Cup, World Cup, Olympic Games and Paralympic Games were also topics of public hearings then called Committee for Tourism and Sport, during the first half of 2013. Yet, there was a seminar with representatives of clubs and the federal government in which debated the debt of Brazilian sports associations with the tax authorities and alterna-

\footnotetext{
${ }^{5}$ Currently this committee is chaired by the deputy Damian Feliciano (PDT/PB), having as 1st Vice-Chairman the deputy Alfonso Hamm (PP/RS), as 2nd Vice-Chairman the deputy Romário (PSB/RJ) and as 3rd vice-Chairman the deputy Marcelo Matos (PDT/RJ). Of these, which has a explicit connected with the sport is the deputy Romário, that was Tetra World Champion Football and named Best Player of the FIFA in the World Cup in 1994.

${ }^{6}$ To access the electronic site of the Committee on Sport in the Chambre of Deputies: <www2.camara.leg.br/atividade-legislativa/comissoes/comissoes-permanentes/cespo/conheca-a-comissao/membros>. Access on: 14 Aug. 2014.
} 
tives and possibilities for agreements with creditors. Among the projects and programs voted by the Committee we have the institution of the National Sports Outreach Program for the Elderly. There were also six technical visits by members of this Committee to the host cities of the Confederations Cup - Brasilia, Belo Horizonte, Recife, Salvador and Fortaleza. In these capitals, deputies visited the stadiums and airports, primarily recording his observations in a final report (Comissão de Turismo e Desporto, 2014). Regarding the second half of 2013 included the provision for a public hearing for August 7 for analyze the results of the hospitality service to generally users, at the Confederations Cup. However, the only record found for this period was the decides of Committee about the Law Bill No. 7560/14 establishing amendments to the Law of Professional Soccer Coach (8.650/93), in relation to contractual liability issue and the club with coaches and athletes (Comissão do Esporte, 2014a).

In 2014, the now named Committee on Sport (Câmara dos Deputados, 2014), among several related activities, there was public hearings on: amendment of the law of contraction of the coaches previously mentioned, racism, and children and adolescents abuse in football clubs, World Cup Soccer (Ministry of Sport's Planning, safety and works in the host cities including airports), resources for the sport coming from New Pelé Law (reformulated in March/2014). Some of these hearings were attended by the Sport Minister and Minister for Cities. Still, there were reports of visiting football stadiums in 3 cities hosting the World Cup, opening of the Gallery Athletes, and debates - about complaints against Brazilian Volleyball Confederation, life insurance for athletes training for competitions, works for Olympic Games, dietary supplements, scholarship athlete for athletes caught in doping test, security at sporting events, allocation of $10 \%$ of scholarship athlete for coaches, a bill law that limits reelection of directors in sport organizations and balance on the World Cup (Comissão do Esporte, 2014b).

\subsubsection{The Committee on Education, Culture and Sports of the Senate}

In the Senate the existing PIS is the Committee on Education, Culture and Sports, a permanent commission composed of 27 senators holders and 27 deputies alternates who analyze the general rules pertaining to education, culture and sports area, such as guidelines and bases for national education, salary premium for education, communication, media, scientific and technological creations, besides, grant award and renewal grant of authorizations for services to radio broadcasting and images. As it turns out, is not a legislative committee focused exclusively on the PPS and that lack of expertise denotes the little central place that the Senate gives to the issue.

This committee has some subcommittees in operation, among them the Permanent Subcommittee of Sport, composed by 7 senators holders and 7 senators alternates, but by August 2014 had not yet been installed (Senado Federal, 2014). ${ }^{7}$ In the electronic site of the

\footnotetext{
${ }^{7}$ As stated in the field Committee on Education Culture and Sports of the Senate website: http://legis.senado.leg. br/comissoes/comissao?6\&codcol=728 >. Access on: 14 Aug. 2014.
} 
Senate can find the agenda, minutes, notes, results and synthesis of committee meetings, as well as judged matters, its rapporteurs, may mark the processes you want to monitor, keeping yourself informed via e-mail at own system. ${ }^{8}$

\subsubsection{The Parliamentary Front of Physical Activity for Human Development}

This Parliamentary Front was created in 2011 with the purpose of promoting actions and develop legislative proposals to ensure people's right to physical activity, because it believes that the practice of physical exercises and sports, as a health promotion tool and citizen formation, is integral part of the constitutional and fundamental rights of Brazilians to access health, sports and education. One of its main commitments is to enjoy the visibility that the Olympic Games (2016), Paralympic Games (2016) and the World Cup (2014) to bring the sport and physical activity for to stimulate, across the country, the practice of exercise guided by a qualified professional. The Parliamentary Front of Physical Activity has a statute that regulates its internal workings (Frente Parlamentar da Atividade Física, 2013), being formed by senators, deputies and a representative of the Federal Council of Physical Education, totaling 175 members.

Formally, this Parliamentary Front has five main objectives, as contained in its website: ${ }^{9}$

i) ensure the constitutional right of the Brazilian people to be able to enjoy the spaces conducive to physical activity; ii) the Brazilian population aware of the importance of physical activity as a means of promoting health; iii) ensure the Brazilian population care by trained and skilled professionals; iv) allocation of funds for maintenance projects assisting in physical activities as well as for renovation and construction of spaces for both; v) ensure compliance with the provisions of Law 9394/96 which regulates the Guidelines and Bases of Education, amended by Law $10328 / 2001$, which required to be shown as Physical Education curriculum component in basic education, seeking to ensure even minimum hours weekly for three days in schools.

To achieve these goals Parliamentary Front proposed publish information on the topic of Physical Activity and enable the creation of virtual forums. However, this was not done. There were only a few isolated actions such as the approval of the guidelines from members in front of the former Commission for Tourism and Sport, to be his last recorded activity on its website dated 17/12/2012.

\footnotetext{
${ }^{8}$ For access to such services of the Committee on Education, Culture and Sports access: <http://legis.senado.leg. br/comissoes/comissao?4\&codcol=47>. Access on: 14 Aug. 2014

${ }^{9}$ Website of Parliamentary Front of Physical Activity: <fpdatividadefisica.com.br>. Access on: 14 Aug. 2014.
} 


\subsubsection{The Parliamentary Front on Sport}

According to data from the Chamber of Deputies website, ${ }^{10}$ the Parliamentary Front on Sport was recorded even before the official record of Parliamentary Fronts by Act № 69/2005 of the Bureau Director of the Chamber of Deputies. Thus, the first record of the Parliamentary Front on Sport date 2/12/2003 during the 52nd Legislature under the chairman the deputie Ivan Ranzolin. The record was kept on 21/05/2006 during the 53rd Legislature chaired chairman the deputie Manuela D'Avila.

Also according to information from the Chamber of Deputies website, there is news that the Parliamentary Front on Sport was relaunched on 17/8/2011 11 with as chairman the former boxer and deputie Acelino Popo (PRB/BA) and as vice-president the deputie Manuela d'Ávila (PCdoB/RS), and the composition of more than 200 deputies and 7 senators, although there is no record date of the Parliamentary Front on Sport of the Chamber of Deputies in 2011. In the website contained the record with the date 09/02/2013 with deputie Acelino Popo (PRB/BA) in the presidency and by deputie Manuela D'Avila (PCdoB/RS) at the vice presidency, and initially composed of 301 deputies and 25 senators, ${ }^{12}$ however, now has record of 198 deputies and 8 senators. This front was established with the goal of making policy proposals and actions related to the valuation of the sportsman and sports. There is no news of current activities since its relaunch, the site and the entity is disabled.

The Parliamentary Front on Sport is often referred to as "Bench of the Ball", in reference to the football, in a materialization of the relationship between commercialization of football and interests of an interest group (Hirata, 2011; Leão Jr., 2004; Bueno, 2008; Veronez, 2005).

However, as we saw in section 4.1 of this article, we know that the Parliamentary Front is not the same as "Bench". Furthermore, considering the few references that there are about "Bench of the Ball", whose informality hampers we get more concrete data, this consists of a few parliamentarians (Bueno, 2008:248; O Estado de S. Paulo, 2012; Cruz, 2014; Damato and Resende, 2014; Rebello and Cruz, 2014; Silva, 2013).

\subsection{Institutions of Executive Branch}

In Brazil, the implementation and monitoring of public policies on the federal level are in charge of the ministries, special secretariat, authorities, regulatory agencies and councils.

\footnotetext{
${ }^{10}$ Dates of registration of Parliamentary Front on Sport as contained in the website of the Chambre of Deputies: <www.camara.gov.br/internet/deputado/frentes.asp>. Access on: 14 Aug. 2014.

${ }^{11}$ As indicated in the Chamber of Deputies website at the link: <www2.camara.leg.br/camaranoticias/noticias/ESPORTES/201102-FRENTE-PARLAMENTAR-DO-ESPORTE-SERA-RELANCADA-HOJE.html>. Access on: 14 Aug. 2014. ${ }^{12}$ As stated in the Chamber of Deputies website at the link: <www2.camara.leg.br/atividade-legislativa/comissoes/ comissoes-permanentes/ctur/noticias/popo-relanca-frente-parlamentar-para-valorizar-o-esporte>. Access on: 14 Aug. 2014.
} 
While these agencies may also to do proposals for the Legislative Branch. Currently, the federal government consists of 26 ministries, 10 secretariats of the Presidency with ministerial status and 25 Councils Policy. ${ }^{13}$ Among these, we have the following executive PIS: Ministry of Sport and National Sport Council. But it was not always so.

The history of executive PIS in Brazil can be reconstituted from Marinho (1952), Castellani Filho (1988), Veronez (2005) e Bueno (2008).

During the Empire the action of state in the sports sector was shy. In 1832 were initiated discussions on the implementation of physical education ${ }^{14}$ in the country; between 1851 and 1889 were approved some laws, decrees and regulations established sports as training in military academies and in 1882 as a pedagogical function in schools. ${ }^{15}$ Thus the practice of sports was autonomous, ie not official and organized privately: between 1870 and 1910 were created in several Brazilian cities over 60 yacht clubs that encourage rowing and also football (Tubino, 1996; Bueno, 2008).

The demand came from various professional sports introduced in Brazil in this period, the first sport introduced in Brazil, the rowing had this demand since 1906 (Veronez 2005:171-172). However, owe to football and its popularity the demand for the development of an organization of Brazilian sport. Introduced in Brazil in 1894, the football gets huge popularity with the creation of regional clubs and leagues (Bueno, 2008:89), however, this popularity has led to disputes over organizational primacy on this modality. These factors demanded the state intervention and the creation of the first PIS in 1916, the Brazilian Sports Confederation (BSC) ${ }^{16}$ from the merger of the football leagues then in existence, and whose function would be to administer the entire Brazilian sport, not just football.

However, the Brazilian Sports Confederation faced difficulties from the lack of public budget and the rivalry of the representatives of Olympic sports. This rivalry stemmed from the fact that the Olympic sports had no autonomy and professionalism that had been conquered

\footnotetext{
${ }^{13}$ The president may, by special law, create and modify the structure and extinguish ministries, departments and agencies of government, and it is also he who appoints the ministers. On the organization of the Brazilian state, see: <www.brasil.gov.br/governo/2009/11/governo-federal-e-formado-por-ministerios-secretarias-e-orgaos-especiais > . Access on: 14 Aug. 2014.

${ }^{14}$ Called Gimnastics.

15 This date was set as a mandatory form in schools, but it was legally established prior to educational practice by Law № 630 of 1851 .

${ }^{16}$ The Brazilian Federation of Sports (BFS) was an entity created on June 8, 1914 by eight entities (Brazilian Aeroclub, Automobile Club of Brazil, Brazilian Equestrian Center, Club Gynástico Portuguese, Central Commission of Contests Equestrian, Brazilian Federation of Societies of Remo, Brazilian Jockey Club and Metropolitan League Sports Athleticos) to manage the Brazilian football. On June 21, 1916, it merged with another Brazilian soccer league managing existing at the time, the Brazilian Federation of Foot-Ball, created last year by the Paulista Football League to give the Brazilian Sports Confederation (BSC) that until 1979 was responsible for organizing not only football but all sports and in the country. In 1979 the BSC ceased to exist and was spun off in Brazilian Football Confederation (BFC) and 30 other confederations other modalities, which passed the supervision of the Brazilian Olympic Committee (BOC) (Brasil, 2013).
} 
by the football ${ }^{17}$ and found it difficulties to keep own ${ }^{18}$, despite the creation of the Brazilian Olympic Committee (BOC) ${ }^{19}$ in 1914 with support from the International Olympic Committee (IOC). Before leaving the Olympic disciplines overhaul the BOC, supplanted by the BSC, and in the Berlin Olympics at 1936 the BOC and the BSC sent delegations to the Olympic Games, generate a serious problem to the IOC (BOC, 2008a e 2008a apud Bueno, 2008). After this fact occur the decentralization of sports management with the creation of the sports federations of Olympic sports, leaving to the BSC only international bureaucratic representation of the State in the sport - this prerogative is assumed by BOC today.

In 1937 as part of a great movement of restructuring and modernization of the Brazilian state in the first Vargas's Government (1930-45) the Division of Physical Education was established in the Ministry of Education and Health. In 1939 the National Sports Commission, a provisional agency created in order to conduct the study of the sport's problems in the country and make for the Federal Government a general plan with sport's regulation.

Introduced in 1941 by presidential decree, during the Estado Novo, the plan established the organization of sport and the creation, within the Ministry of Education and Health, of the National Council of Sport instituted with the objective of ensuring the nationalist orientation, control and unify sports entities and to do regulations in order to settle conflicts. However, was kept the existence of the BSC and the BOC. The BSC, in turn, responsible for promoting both the professional sport as an amateur, later acquired great status with the growth of football and the organization of the World Cup in Brazil in 1950. In 1941 it also created the Brazilian Confederation of University Sports, by the Minister Capanema, aimed at structuring the university sports along the lines of the current model in the United States, because the sport was seen as a way of providing legitimacy to the regime and the identity and cohesion of the nation.

The return to democratic government in 1945 did not alter the pattern of public policy for sport, implemented by authoritarianism. The Federal Constitution of 1946, for example, even cites the sport, only strengthening the structure previously established. The

\footnotetext{
${ }^{17}$ For more information about the professionalisation of football in Brazil see: Benites, Barbieri and Souza Neto (2007:51-68).

${ }^{18}$ Even in the years 1924 and 1928 there were no Brazilian participation in the Olympic Games because the BSC and the government claimed to have no budget to fund the delegation. In 1932 the athletes had to work on a cargo ship coffee to fund his trip to the Olympic Games in Los Angeles. For information, see: "The games in Brazil — Summer Olympic Games — Los Angeles 1932". In: < http://timebrasil.cob.org.br/brasil-nos-jogos/jogos-olimpicos/los-angeles-1932>; and "The games in Brazil — Summer Games - 1936 in Berlin". In: <http://timebrasil.cob.org.br/ brasil-nos-jogos/jogos-olimpicos/berlim-1936>. Access on: 14 Aug. 2014.

${ }^{19}$ The BOC is a non-governmental organization of private law that is intended to represent the spread Olympism and the Olympic ideal in Brazil. Acts in technical and administrative management of sport in the development of Olympic Sports in Brazil, and in representing the country at sporting events. Its autonomy is guaranteed by the Constitution of Brazil. Its mission is to act in high performance sport. The BOC was founded on June 8, 1914, at the Brazilian Federation of Societies of Remo, on the initiative of the Metropolitan League of Athletic Sports. Because of World War I, only in 1935 the organization became operational in fact.
} 
only addition to legislative action, related to sports policy was the Decree № 9912/1946 that went to the President of the Republic to award the construction of sports courts and appointing a commission to study and specific proposals for the subject. In this period we also had the National Campaign of Physical Education, established by Decree № 43 $177 / 1958$ with the aim of "promoting the necessary development of physical education to their diffusion, the improvement of specialized measures and the installation of Physical Education Centers". In the period 1944-59 there was progressive increase in the number of Confederations, state and territorial federations, football clubs (large and small), leagues and other entities connected to the National Council of Sport, with a corresponding increase in the volume of resources allocated to them. In May 1969 was established an agreement between the Institute of Applied Economic Research, an agency of the Ministry of Planning and General Coordination and the Division of Physical Education of the Ministry of Education and Culture, to prepare the Diagnosis of Physical Education and Sports in Brazil which is published in 1971.

In the second dictatorship of the $20^{\text {th }}$ century in Brazil there were more changes in PIS. In 1970 was created the Federal Lottery Sports ${ }^{20}$ based on results of football matches, and whose income was allocated to the BSC in its function of administering the Brazilian sport interestingly his first bet was on results of games of the World Cup. In 1971 the Division of Physical Education of the Ministry of Health and Education was renamed for Department of Physical Education of Sports and reallocated to Ministry of Education and Culture, as a fruit of the Diagnosis of Physical Education and Sports in Brazil sponsored by the government of General Medici, which also promoted the Plan of Physical Education and Sport. This Plan, comprising 16 projects, intended to attack the problems of low physical fitness of the population, the shortage of skilled professionals and the ineffectiveness of federal government for control and planning this area until then. Subsequently the Department of Physical Education of Sports is transformed into the Secretariat of Physical Education and Sports also under the Ministry of Education and Culture, showing an increase of this issue in the administrative hierarchy and politic.

In 1975, already in the government of General Geisel, the state will allocate public resources specific to the sport beyond those provided by the Federal Sports Lottery, as well authorizes the donations from private companies allows the sports entities with tax exemption of up to $5 \%$. From this change in legislation the marketing entry into the Brazilian professional sports. In addition, the Sports Lottery also began to allocate the total net income to BOC, of a weekly contest in each year that were performed Olympics and the World Cup for the cost

\footnotetext{
${ }^{20}$ Currently, among the current sources of funding for the sport in Brazil, a large part comes from the Federal Sports Lottery, which gives $10 \%$ to Football Clubs and 15\% to the Ministry of Sport, which is passed on to the Brazilian Olympic Committee and the Committee Brazilian Paralympic, which still receive 25\% every four years to fund the Brazilian delegation for participation in the Olympic and Paralympic Games.
} 
of delegations. ${ }^{21}$ Yet in 1975 was created the Federation of Professional Athletes Associations earmarked for social and educational assistance to professionals athletes, former athletes and athletes in training.

In 1979, under the government of General Figueiredo, BSC was split into Brazilian Football Confederation (BFC) and over 30 other specific confederations for other sports which is supported by the BOC, which forwards them to funds received from the government through the Lottery Federal sports. It is important to remember that the BSC has emerged from football bodies, and that from the surplus obtained with the creation of the Federal Sports Lottery, BSC wanted to be dismembered in sports confederations believing that each sport would be able to take its own administrative and financial autonomy. ${ }^{22}$

In 1993, under President Itamar Franco, the former National Council of Sport is replaced by the Higher Sports Council that became an advisory body/regulatory, losing deliberative and executive functions. The Secretariat of Physical Education and Sports in Ministry of Education and Culture was transformed into the new Secretariat of Sports in the new Ministry of Education and Sports, established in 1992, during the Collor administration. In this year was also instituted the "Federal System of Sport" which set the BOC and sports federations such federal entities of administration of sport and instituted the Sports Justice. ${ }^{23}$

In 1995, at the beginning of the Cardoso government, the office of Special Minister of Sport, ${ }^{24}$ occupied by Pele, was created and located at the Ministry of Education and Sport. Also that year the National Institute of Sports Development ${ }^{25}$ (NISD), a federal agency that would be the executive body of the sport in order to provide technical and administrative support to the Special Minister of State of Sports was created in addition to the existing Secretariat of Sports. Even not having the status of a ministry, the sport had been progressing in the administrative and political hierarchy. The NISD had as functions implement decisions concerning sport policy, carry out studies in the area and raise funds to finance programs in sport - one way of raising funds managed by NISD was Bingo.

In $1998^{26}$ he was once again redefined the "Federal System of Sport" - which the actual law is also called, in a schizophrenic manner, of "National Sports System" and too "Brazilian System of Sport" - replacing the Secretariat of Sports by the National Institute of Sports Development and renaming the Higher Sports Council by Brazilian Council to Development to Sport — which in the its 11 vacancies the Minister indicated nine members, always ensuring

\footnotetext{
${ }^{21}$ For more information on the funding of the sport in Brazil, see Bueno (2008).

${ }^{22}$ Sports federations and confederations, as well as the Brazilian Olympic Committee and Paralympic Committee Sports are private institutions — as Decree № 7984/2013 — not constituting PIS, but this study cited only by their interface with the first PIS of Brazil, CBD.

${ }^{23}$ Law Zico - Law no 8.672/1993.

${ }^{24}$ By Provisional Measure no 813 of 1/1/1995.

${ }^{25}$ The National Institute of Sports Development was established by Decree no 1.437, of 4/4/1995.

${ }^{26}$ Law Pelé — Law no 9.615/1998.
} 
the most of the council for government and the ability to impose their vision and projects. This year is also created the Brazilian Paralympic Committee. ${ }^{27}$

In 1999, during the second Cardoso's government, the Ministry of Education and Sport is dismembered in the Ministry of Education and Ministry of Sports and Tourism, thus specializing the first time the functions of each ministerial areas, without ensuring due importance to the sport since, the organization chart, it starts to work with the tourism policy.

In 2000 the National Institute of Sports Development is closed for administrative misconduct due to allegations of irregularities in the authorization and control of bingo's process, ${ }^{28}$ and the Caixa Econômica Federal shall take care of this game of chance. It is created on a temporary basis the Sectorial Chamber of Sports with the old features of NISD, composed of athletes, former athletes, managers, coaches, researchers, jurists and even sponsors, aiming to develop a National Plan of Sport should be finalized the first proposal in 2012. The first propose of this Sectorial Chamber of Sports was the creation of the National Secretariat of Sports, who took over the functions of former Nisd and of the National Athletes Commission, ${ }^{29}$ composed by 35 athletes and/or formed athletes and with the purpose of advising policy sports, both under the Ministry of Sport and Tourism.

In 2002, the last year of the Cardoso government, the Brazilian Council of to Development to Sport is renamed the National Council of Sport (NSC). In 2003, early in the first Lula government, the Ministry of Sports and Tourism is dismembered in the Ministry of Tourism and Ministry of Sport. In 2003, although it has not created institutions, but there are two laws bring important innovations to Brazilian football clubs: the Statute of the Fan and Law ${ }^{30}$ of Moralisation for Clubs. ${ }^{31}$ The figure 2 shows the evolutionary chart of PIS on Executive power in Brazil.

\footnotetext{
${ }^{27}$ The Brazilian Paralympic Committee, as well as the Brazilian Olympic Committee, is a non-governmental organization working in private law representation and leadership of the Brazilian Paralympic movement seeking promotion and the development of high performance sport for people with disabilities.

${ }^{28}$ One way of funding the sport managed by the National Institute of Sports Development was Bingo. The complaints about irregularities in the licensing process control and bingos led federal prosecutors to go to court with administrative misconduct action against the Minister of Sports and Tourism, Rafael Greca, and their advisors. The complaint involved the sale of Provisional Measure that overturned the ban on electronic bingo machines, included in Pelé Law. Greca left the ministry on 5/5/2000 and 27/10/2000, the application of the new Minister of Sport and Tourism Carlos Melles, Indesp was extinguished by the Provisional now the Federal Savings assignments relating to the bingo game. For more information see: <www2.oabsp.org.br/asp/clipping_jur/ClippingJurDetalhe.asp?id noticias=7317\&AnoMe $>$ and <www.senado.gov.br/comissoes/cpi/bingos/relfinalbingos.pdf>. Access on: 14 Aug. 2014 . ${ }^{29}$ For more information about the National Athletes Comission see: <http://portal.esporte.gov.br/institucional/ comissoes/cna/default.jsp>. Access on: 14 Aug. 2014.

${ }^{30}$ Law of Right's Fan - Law № 10.671/20013. Establishes the rights of fans.

${ }^{31}$ Law Moralisation Clubs - Law № 10.672/2003. Determines which entities of sports practices are governed by the Civil Code, which imposes the structure of the sport, more transparent rules and the mandatory publication of balance sheets and audit accounts by independent auditors, in blaming the leaders of bad administration.
} 
Figure 2

\section{Organogram evolutionary of executive PIS in Brazil ${ }^{32}$}

\begin{tabular}{|c|c|c|}
\hline 1916 & 1937 & 1939 \\
\hline \multirow[t]{4}{*}{$\begin{array}{l}\text { BRAZILIAN SPORTS } \\
\text { CONFEDERATION } \\
\text { (BSC) }\end{array}$} & $\begin{array}{l}\text { MINISTRY OF } \\
\text { EDUCATION AND } \\
\text { HEALTH (MEH) }\end{array}$ & $\begin{array}{l}\text { NATIONAL } \\
\text { SPORTS } \\
\text { COUNCIL }\end{array}$ \\
\hline & Education (DPE) & $\begin{array}{l}\text { MINISTRY OF } \\
\text { EDUCATION AND }\end{array}$ \\
\hline & $\begin{array}{l}\text { BRAZILIAN SPORTS } \\
\text { CONFEDERATION } \\
\text { (BSC) }\end{array}$ & $\begin{array}{l}\text { HEALTH (MEH) } \\
\text { - Division of Physical } \\
\text { Education (DPE) }\end{array}$ \\
\hline & & $\begin{array}{l}\text { BRAZILIAN SPORTS } \\
\text { CONFEDERATION } \\
\text { (BSC) }\end{array}$ \\
\hline
\end{tabular}

\begin{tabular}{|c|c|}
\hline 1941 & 1971 \\
\hline $\begin{array}{c}\text { NATIONAL } \\
\text { SPORTS } \\
\text { COUNCIL }\end{array}$ & $\begin{array}{c}\text { NATIONAL } \\
\text { SPORTS } \\
\text { COUNCIL }\end{array}$ \\
\hline $\begin{array}{c}\text { MINISTRY OF } \\
\text { EDUCATION AND } \\
\text { HEALTH (MEH) } \\
\text { - Division of Physical } \\
\text { Education (DPE) }\end{array}$ & $\begin{array}{c}\text { MINISTRY OF } \\
\text { EDUCATION AND } \\
\text { CULTURE (MEC) } \\
\text { - Secretary of Sports } \\
\text { and Physical } \\
\text { Education (SSPE) }\end{array}$ \\
\hline $\begin{array}{c}\text { BRAZILIAN SPORTS } \\
\text { CONFEDERATION } \\
\text { (BSC) }\end{array}$ & $\begin{array}{c}\text { BRAZILIAN SPORTS } \\
\text { CONFEDERATION } \\
\text { (BSC) }\end{array}$ \\
\hline $\begin{array}{c}\text { BRAZILIAN } \\
\text { CONFEDERATION } \\
\text { OF UNIVERSITY } \\
\text { SPORTS (BCUS) }\end{array}$ & $\begin{array}{c}\text { BRAZILIAN } \\
\text { CONFEDERATION } \\
\text { OF UNIVERSITY } \\
\text { SPORTS (BCUS) }\end{array}$ \\
\hline
\end{tabular}
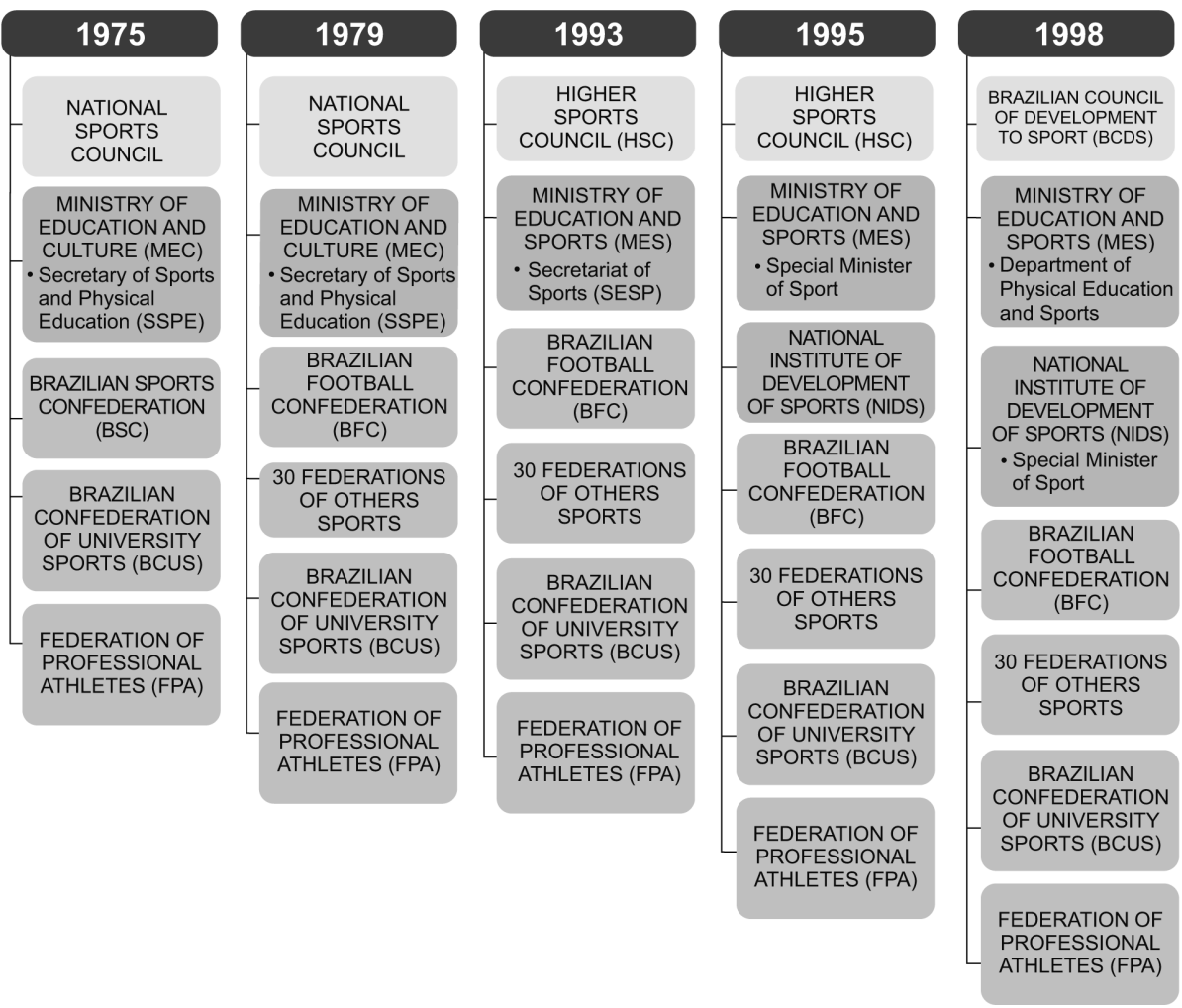

Source: Own elaboration based on data from the Bueno (2008).

\footnotetext{
${ }^{32}$ In this figure are only positioned the PIS as its creation and / or presence in that year, not as a hierarchy among them.
} 
The overall logic that governs these transformations in the institutional configuration of the Brazilian State turned the PPS is the same that other areas of policies: for each new issue that arises and that demand regulation, a new bureaucracy is added to the structures of government. This is a way to nationalize the demands of public policy without necessarily resolving them. The increasing complexity of organization charts do not necessarily translate into increased ability of the state to solve problems. Those devices that are being created, dissolved, recreated over time seem to be, rather, the product of the ability of bureaucrats to formulate and pursue goals from set their own priorities. Nordlinger and partners (1988) observe most appropriately "preferences [of the state officials] are shaped by organizational needs and rivalries over the government policy to be followed, on budget, on [the degree] internal autonomy and prestige [that enjoy]. Therefore, "state officials prefer policies that help to structure and strengthen its autonomy" (Nordlinger et al., 1988:882). An example of this is the case, cited above, is the change of the Brazilian Council to Development to Sport and its successor, the National Council of Sport.

\subsubsection{National Council of Sport (NSC)}

Created in 2002 to succeed the Brazilian Council of to Development to Sport, the NSC is still, in 2014, a collegiate to advise the Minister of Sport. The NSC has webpage ${ }^{33}$ in thewebsite of Ministry of Sport with information about the college, who are pointing their members, existing committees, minutes of meetings, resolutions, laws and documents. The formal objective of the NSC is "to develop programs that promote the intensive and planned practice of physical activity for the entire population, in addition to improving the standard of organization, management, quality and transparency of the sector" (Ministério do Esporte, 2012).

The composition of NSC over time was compiled by Lorenzo (2008), who used the information of Linhales (1996) and Manhães (2002). Since 2003 the NSC is composed of 22 members, as shown in frame 1.

Lorenzo (2008) it was found that the National Council of Sport has a drawing little institutionalized, mainly because the regulation does not define clearly the selection and roles of counselors, and the agenda features low capacity for discussions and to incorporate new demands. The interactions between the counselors and the structural and organizational aspects studied by Lorenzo (2008) characterize a timid participation, dependent on state and toward specific segments of the sports initiative - which is exemplified by the fact that football is the only sport that its confederation, the Brazilian Football Confederation, have a seat in the council. Being a council for policy in order to promote social control and participation by incor-

\footnotetext{
${ }^{33}$ To access the electronic site of the National Council of Sport, visit: <www.esporte.gov.br/index.php/institucional/o ministerio/conselho-the-national-sport->. Access on: 14 Aug. 2014.
} 
porating the demands of sport policy, the National Council of Sport does not act effectively, especially when compared to other boards, such as the National Health Council - upon which a research of the National Institute of Applied Economic Research found that $71 \%$ of advisers point to the influence of the NHC in public policy from the Ministry of Health as a significant or very significant Ipea (2012).

\section{Frame 1 \\ Composition of NSC}

\begin{tabular}{|c|c|}
\hline Type Members & Members (22) \\
\hline $\begin{array}{l}\text { Government } \\
\text { (5 members) }\end{array}$ & $\begin{array}{l}\text { Sport Minister } \\
\text { Executive Secretariat of the Ministry of Sports } \\
\text { National Secretariat of Sport High Performance } \\
\text { National Secretariat of Sports, Education, Leisure and Social Inclusion } \\
\text { National Secretary of Football and Defense of Fan's Rights }\end{array}$ \\
\hline $\begin{array}{l}\text { Entities } \\
\text { (11 members) }\end{array}$ & $\begin{array}{l}\text { Representative of the Brazilian Olympic Committee } \\
\text { Representative of the Brazilian Paralympic Committee } \\
\text { Representative of the National Commission for Athletes } \\
\text { Representative of the National Forum of State Secretaries of Sporting } \\
\text { Representative of Municipal Managers and Secretaries of Sporting } \\
\text { Representative of Social Clubs } \\
\text { Representative of the Federal Council of Physical Education } \\
\text { Representative of the Brazilian College of Sport Science } \\
\text { Representative of the Brazilian Military Sports Commission } \\
\text { Representative of the National Organization of National Leaders of Sports Entities } \\
\text { Representative of the Brazilian Football Confederation }\end{array}$ \\
\hline $\begin{array}{l}\text { Subjects } \\
\text { (6 members) }\end{array}$ & $\begin{array}{l}\text { Representative of Sports } 1 \\
\text { Representative of Sports } 2 \\
\text { Representative of Sports } 3 \\
\text { Representative of Sports } 4 \\
\text { Representative of Sports } 5 \\
\text { Representative of Sports } 6\end{array}$ \\
\hline
\end{tabular}

Source: Own elaboration based on data from the Ministério do Esporte (2012). 


\subsubsection{Ministry of Sport (MS)}

The Ministry of Sport is defined as the institution:

responsible for building a National Sports Policy. In addition to developing high performance sport, the Ministry works actions of social inclusion through sports, ensuring the Brazilian population free access to sports practice, quality of life and human development (Brasil, 2014)

Among its actions are several programs developed by each of the National Secretariats that are part of this ministerial office, as shown in Frame 2. The National Secretariat of Sports, Education, Leisure and Social Inclusion oversees 10 projects, the National Secretariat of Football and Right's Fan has 5 projects and the National Secretariat of Sport High Performance concerned with 10 projects. There is a disparity in terms of structure and demand of labor in departments.

Frame 2

\section{Composition of the programs of the National Secretariats in MS}

\begin{tabular}{|c|c|c|}
\hline $\begin{array}{l}\text { National Secretariat of Sports, Education, } \\
\text { Leisure and Social Inclusion }\end{array}$ & $\begin{array}{l}\text { National Secretariat of } \\
\text { Football and Right'sFan }\end{array}$ & $\begin{array}{l}\text { National Secretariat of Sport High } \\
\text { Performance }\end{array}$ \\
\hline $\begin{array}{c}\text { Sport after the School } \\
\text { Sport in the School } \\
\text { Recreation in the Vacations } \\
\text { Sport and Leisure in the City } \\
\text { Competitions and Events of Sport and Leisure } \\
\text { Indigenous Games } \\
\text { A network to sport's research called CEDES } \\
\text { Brazil Award for Sport and Recreation Social } \\
\text { Inclusion } \\
\text { Painting the Freedom }\end{array}$ & $\begin{array}{c}\text { Fifa World Cup } 2014 \\
\text { Women's Soccer } \\
\text { Timemania } \\
\text { Cool Fans } \\
\text { Guide to Football Stadiums }\end{array}$ & $\begin{array}{l}\text { Center for Sports Initiation } \\
\text { Plan Brazil Awards } \\
\text { National Training Network } \\
\text { Athlete scholarship } \\
\text { National Sports Calendar } \\
\text { Brazilian School Games } \\
\text { Military Games } \\
\text { Olympic Games Rio } 2016 \\
\text { Paralympic Games Rio } 2016\end{array}$ \\
\hline
\end{tabular}

Source: Own elaboration based on data from the Brasil (2014). The names of the programs were translated, seeking the best possible match with the English, without distorting the marketing name.

In August 2011, the Special Adviser Soccer gave way to the National Secretariat of Football and Right's Fan, highlighting once again the importance of football compared to other sports in Brazil, and especially the importance of the interests involved in it (Veronez, 2005; Bueno, 2008). 
Figure 3

\section{Organogram actually of Ministry of Sport}

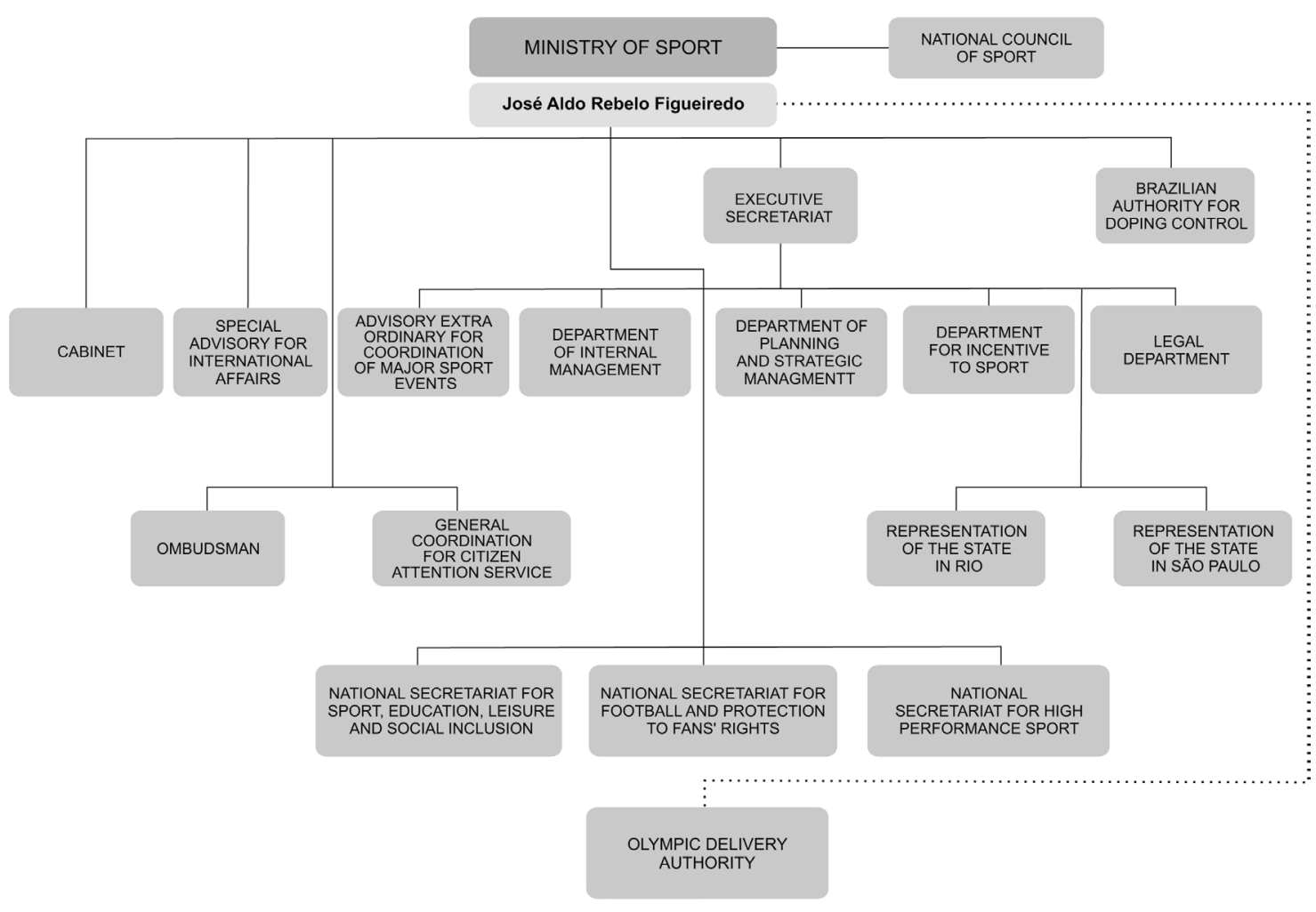

Source: Own elaboration based on data from the Brasil (2014).

\section{Problems of the political institutions for sport in Brazil}

This article pointed out how are the PIS in Brazil, their goals legally established, their structure and their managers and/or policy makers. A summary of the PIS can be seen in the Frame 3.

The sport, though politically debated in Brazil since 1832, only in 1916 established its first executive PIS, the old BSC, and only in 1983 saw the birth of the first legislative PIS, the current Parliament's Committee on Sport.

Regarding formal legislative PIS, the Committee on Education, Culture and Sport in Senate and the Parliament's Committee on Sport in Chamber of Deputies, we can imagine, optimistically, that the bicameral system allows for greater discussion of the laws that are proposals. However, openness to new propositions depends on coordination with the managers of these PIS. Commendably the transparency of their actions through the dissemination via the Internet (plus the Chamber of Deputies that the Senate). Regarding informal legislative PIS, 
the Parliamentary Front on Sport and Parliamentary Front on Physical Activity for Human Development and noticed small numbers and lack of transparency in their actions. However, the initiative of the Parliamentary Fronts is a breakthrough in the search for improvement of legislation by a group interested in the subject, since the standing committees of the chambers has a limited number of participants, though, there is also the possibility that the Parliamentary Fronts may also be the focus of lobbying, practice outlawed in Brazil.

Frame 3

Summary of structure of PIS in Brazil

\begin{tabular}{|c|c|c|c|c|}
\hline \multicolumn{2}{|c|}{ Structure of PIS } & \multirow{2}{*}{$\begin{array}{c}\text { Function } \\
\text { Elaboration of general } \\
\text { rules for the field of } \\
\text { education, culture and } \\
\text { sports }\end{array}$} & \multirow{2}{*}{$\begin{array}{l}\text { Members } \\
7 \text { senators }\end{array}$} & \multirow{2}{*}{$\begin{array}{c}\text { Managers and/or Policymakers } \\
\text { Senators elected, appointed to } \\
\text { compose the commission by } \\
\text { partisan proportionality in National } \\
\text { Congress }\end{array}$} \\
\hline \multirow{4}{*}{ Legislatives } & $\begin{array}{l}\text { Committee } \\
\text { on Education, } \\
\text { Culture and } \\
\text { Sports }\end{array}$ & & & \\
\hline & $\begin{array}{l}\text { Committee on } \\
\text { Sport }\end{array}$ & $\begin{array}{l}\text { Regulate the national } \\
\text { sports system and the } \\
\text { national plan for physical } \\
\text { education and sport }\end{array}$ & 21 deputies & $\begin{array}{c}\text { Deputies elected, appointed to } \\
\text { compose the commission by } \\
\text { partisan proportionality in National } \\
\text { Congress }\end{array}$ \\
\hline & $\begin{array}{c}\text { Parliamentary } \\
\text { Front on } \\
\text { Physical Activity }\end{array}$ & $\begin{array}{c}\text { Nonpartisan association } \\
\text { to improve legislation } \\
\text { on sport }\end{array}$ & $\begin{array}{l}175 \text { among } \\
\text { senators and } \\
\text { deputies, and } 1 \\
\text { representative do } \\
\text { FCPE }^{1}\end{array}$ & $\begin{array}{l}\text { Deputies and Senators - } \\
\text { participation is free }\end{array}$ \\
\hline & $\begin{array}{l}\text { Parliamentary } \\
\text { Front on Sport }\end{array}$ & & $\begin{array}{c}8 \text { senators and } 198 \\
\text { deputies }\end{array}$ & \\
\hline \multirow[t]{2}{*}{ Executives } & $\begin{array}{l}\text { National } \\
\text { Council of } \\
\text { Sport }\end{array}$ & $\begin{array}{l}\text { Development of } \\
\text { programs that promote } \\
\text { physical activity for the } \\
\text { population, improvement } \\
\text { of sport management } \\
\text { (organization and } \\
\text { transparency) }\end{array}$ & $\begin{array}{l}22 \text { members, } \\
\text { among } \\
\text { government, } \\
\text { entities and } \\
\text { representative of six } \\
\text { modalities of sport }\end{array}$ & $\begin{array}{l}\text { Representative of Government (5), } \\
\text { representatives of Entities (11), e } \\
\text { representatives of some modalities } \\
\text { of sport (6) }\end{array}$ \\
\hline & $\begin{array}{l}\text { Ministry of } \\
\text { Sport }\end{array}$ & $\begin{array}{l}\text { Construction of the } \\
\text { National Sports Policy, } \\
\text { development of high } \\
\text { performance sport, and } \\
\text { free access to sports }\end{array}$ & $\begin{array}{l}279 \text { public } \\
\text { servants }\end{array}$ & $\begin{array}{l}\text { The Minister, appointed by the } \\
\text { President of the Republic, as well as } \\
\text { the National Secretaries that him will } \\
\text { indicate }\end{array}$ \\
\hline
\end{tabular}

Source: Own elaboration.

1 The FCPE is the Federal Council of Physical Education, created by Law No 9.696/1998, which regulates the profession of Physical Education and created their Federal Council of Physical Education and Regional Councils - with controversies.

2 Information obtained in the Transparency Portal at: <www.portaldatransparencia.gov.br/servidores/OrgaoLotacao-ListaOrgaos.asp? CodOS=29000>. Acess on: 14 Aug. 2014.

Regarding Executive PIS, some inconsistencies are evident.

The National Council of Sport aims to democratize access to the sport by population, in the sense of what sets the Constitution of the country (1988). In contrast, the Ministry of 
Sport focuses its actions in elite sport — and this was proven by Bueno (2008) and Veronez (2005) — , aiming to representation of the country in international sports competitions. This is evident in his organogram, which brings together the sport of participation and education in a single Secretariat, and also holds an exclusive Secretariat for football, sports practice that requires, in Brazil, huge government support for its realization. Although the composition of the National Council of Sport has had two changes (referring to the two departments in the Ministry of Sport and the insertion of Brazilian Authority for Doping Control) after the search of Lorenzo (2008), their conclusions are still relevant: (1) the regulation of the council did not define clearly the form of selection and duties of directors; (2) the agenda and guided thematic in Council denote a low capacity for in-depth discussions of topics and incorporating new demands, and (3) the National Council of Sport represents a small contribution as a space for broader participation of society in the incorporation demands of the sport policy and social control over this policy. It is remarkable transparency of the actions of the National Council of Sport, registered on its website. But their actions have been sporadic and have been its last meeting on 20/03/2014 and 10/17/2013 in the above. ${ }^{34}$

However, we must recognize that the Ministry of Sport has advanced, establishing a series of international agreements, but still has structural limitations such as the low number of public servants - there are 279 compared to 305 servants in the Ministry of Tourism ${ }^{35}$, 866 in the Ministry of Environment ${ }^{36}$ and 939 in the Ministry of Culture ${ }^{37}$ - a fact pointed at assessment report prepared by the Ministry of Sport by the Ministry of Planning and Investment (Brasil, 2008).

Regarding the lack interaction between political institutions of Brazilian sport, we mention two emblematic examples:

(1) the rivalry between the BSC and the BOC in the formation of the Brazilian delegation that was in the Olympic Games of 1935 (Bueno, 2008) which is reproduced today in the dispute between the BOC and the National Secretariat of Sport High Performance in Ministry of Sports, regarding the promotion of Olympic sports, and concerning programs and projects to support the athletes that integrate the Brazilian delegation in international sports competitions;

(2) total disruption of the Ministry in relation to the data about Athlete Scholarship on Ministry of Sports (Guimarães, 2009), the program may be evidence that the institution is not

\footnotetext{
${ }^{34}$ Information obtained in webpage of National Council of Sport in the website of Ministry of Sport: <www.esporte. gov.br/index.php/institucional/o-ministerio/conselho-nacional-do-esporte/reunioes>. Access on: 14 Aug. 2014 ${ }^{35}$ Information obtained in the Transparency Portal at: <www.portaldatransparencia.gov.br/servidores/OrgaoLotacao-ListaOrgaos.asp?CodOS $=54000>$. Access on: 14 Aug. 2014.

${ }^{36}$ Information obtained in the Transparency Portal at: <www.portaldatransparencia.gov.br/servidores/OrgaoLotacao-ListaOrgaos.asp?CodOS=40111>. Access on: 14 Aug. 2014.

${ }^{37}$ Information obtained in the Transparency Portal at: <www.portaldatransparencia.gov.br/servidores/OrgaoLotacao-ListaOrgaos.asp?CodOS=40107>. Access on: 14 Aug. 2014.
} 
structured properly to manage this policy, as occurred with the "Program of Sport after the School" of the Ministry of Sport ${ }^{38}$.

\section{Conclusions}

This article tries to reconstruct the evolution of the institutional configuration that produces public policies for sport in Brazil in order to contribute to their best knowledge and raise some issues to think of a more appropriate the establishment of a public policy decision -making structure design that is effective and democratic.

There are basically four problems arising from the organization of the Brazilian sports management: (1) inadequate institutional structure in terms of human resources (Ministry of Sports) and democratic participation (National Council of Sport); (2) disconnection between the institutions generating rework by the PIS (Brazilian Olympic Committee and National Secretariat of Sport High Performance in Ministry of Sport); (3) inadequate planning evidenced in the lack of organization of some institutions, such as the management of Athlete Scholarship by Ministry of Sports and (4) lack of evaluation and lack of continuity of public policies on sport in the Ministry of Sport.

There are challenges of sport policy in Brazil, as rethink an institutional design that allows the mission to deliver sport on Constitution (1988), as well as aiming to improve its management efficiency and transparency.

\section{References}

ALCOFORADO, Michel F. Cenas da política: uma etnografia do plenário do Senado Federal. Dissertação (mestrado) — Departamento de Antropologia, Universidade de Brasília. Brasília, 2010.

ALMEIDA, Bárbara S. de et al. Federal government funding and sport: the case of Brazil 2004-2009. International Journal of Sport Policy and Politics, v. 4, n. 3 - Special Olympic and Paralympic Policy, p. 411-426, 2012.

ALMEIDA, Bárbara S. de; MARCHI JUNIOR, Wanderley. O Comitê Olímpico Brasileiro e o financiamento das confederações brasileiras. Revista Brasileira de Ciências do Esporte B1, v. 33, n. 1, p. 163-179, 2011.

BENITES, Larissa C.; BARBIERI, Fabio Augusto; SOUZA NETO, Samuel de. O futebol: questões e reflexões a respeito dessa "profissão". Pensar a Prática, v. 10, n. 1, p. 51-68, 2007.

\footnotetext{
${ }^{38}$ For more information about the allegations against the Program Sport After the School see: <www2.camara.leg. br/camaranoticias/noticias/ADMINISTRACAO-PUBLICA/203978-OPOSICAO-PEDE-INVESTIGACAO-DE-DENUNCIACONTRA-MINISTRO-DO-ESPORTE.html>. Access on: 14 Aug. 2014.
} 
BERGSGARD, Nils A. et al. Sport policy: a comparative analysis of stability and change. First Edit. Burlington: Elsevier and Book Aid International, 2007.

BRASIL. Decreto n. 4.201, de 18 de abril de 2002. Dispõe sobre o Conselho Nacional do Esporte e dá outras providências. Avaliable at: <www.esporte.gov.br>. Access on: 8 Aug. 2013.

BRASIL. Esporte. Avaliable at: <www.brasil.gov.br/sobre/esporte>. Access on: 6 Aug. 2013.

BRASIL. Ministério do Esporte. Access on: <www.esporte.gov.br>. Access on: 2 Aug. 2014.

BRASIL. Relatório de Avaliação do Plano Plurianual 2004-2007 - Ministério do Esporte - Caderno 19. Brasília: Ministério do Planejamento, Orçamento e Gestão. Secretaria de Planejamento e Investimentos Estratégicos, 2008. Avaliable at: <http://scholar.google.com/scholar?hl=en\&btnG=Search\&q=intitle:MinistĐrio+do+esporte\#2>. Access on: 8 Aug. 2013.

BRUSCO, Dilsson Emílio (Câmara dos Deputados). Histórico das comissões permanentes da Câmara dos Deputados 1823-2004. Brasília: Coordenação de Publicações da Câmara dos Deputados, 2006. (Ação Parlamentar n. 337).

BUENO, Luciano. Políticas públicas do esporte no Brasil: razões para o predomínio do alto rendimento. Tese (doutorado) — Escola de Administração de Empresas, Fundação Getulio Vargas, São Paulo, 2008.

BURGOS, Marcelo B.; TELLES, Sarah S. Elites burocráticas, dirigentes públicos e política no Poder Executivo do Brasil (1995-2012). In: D’ARAUJO, Maria Celina (Org.). Redemocratização e mudança social no Brasil. Rio de Janeiro: FGV, 2014. p. 205-229.

CÂMARA DOS DEPUTADOS. Ato da Mesa no 69 de 10/11/2005a. Portal Câmara dos Deputados, 2005. p. 8. Avaliable at: <www2.camara.leg.br/legin/int/atomes/2005/atodamesa-69-10-novembro-2005-539350-publicacaooriginal-37793-cd.html> . Access on: 26 June 2014.

CÂMARA DOS DEPUTADOS. Diário da Câmara dos Deputados, v. Ano LX, n. 197, p. 237, 2005b. Avaliable at: <http://scholar.google.com/scholar?hl=en\&btnG=Search\&q=intitle:Di-Drio+da+c-Dmara+dos+deputados\#0>. Access on: 22 June 2014.

CÂMARA DOS DEPUTADOS. Resolução da Câmara dos Deputados no 54 de 2014. Diário da Câmara dos Deputados, v. Suplemento, p. 3, 2014.

CASTELLANI FILHO, Lino. Educação física no Brasil: a história que não se conta. Campinas: Papirus, 1988.

CASTELLANI FILHO, Lino O esporte e a Nova República. Corpo \& Movimento Apef/SP, n. 4, p. 7-10, abr. 1985.

CASTRO, Suélen B. E. de et al. O estado da arte em políticas sociais de esporte e lazer no Brasil (2000-2009). Pensar a Prática, v. 15, n. 2, p. 272-550, 2012.

CHALIP, Laurence H. et al. National sports policies: an international handbook. Londres: Greenwood, 1996. 
COMISSÃO DO ESPORTE. Câmara analisa novas regras de trabalho para técnicos de futebol. Avaliable at: <www2.camara.leg.br/atividade-legislativa/comissoes/comissoes-permanentes/cespo/noticias/ camara-analisa-novas-regras-de-trabalho-para-tecnicos-de-futebol>. Access: 12 Aug. 2014a.

COMISSÃO DO ESPORTE. Notícias. Avaliable at: <www2.camara.leg.br/atividade-legislativa/ comissoes/comissoes-permanentes/cespo/noticias>. Access on: 13 Aug. 2014b.

COMISSÃO DE TURISMO E DESPORTO. Available at: <www2.camara.leg.br/atividade-legislativa/ comissoes/comissoes-permanentes/CTS>. Access on: 2 Aug. 2014.

CORADINI, Odaci Luiz. Frentes parlamentares, representação de interesses e alinhamentos políticos. Revista de Sociologia e Política, v. 18, n. 36, p. 241-256, 2010.

CRUZ, José. Quem é quem na "bancada da bola". UOL Esporte. Avaliable at: < http://josecruz. blogosfera.uol.com.br/2014/05/quem-e-quem-na-bancada-da-bola-2/> . Access on: 11 June 2014.

DACOSTA, Lamartine P. The State versus free entreprisein sports policy: the case of Brazil. In: CHALIP, Laurence; JOHNSON, Arthur; STACHURA, Lisa (Org.). National sports policies. Londres: Greenwood, 1996. p. 23-38.

DAMATO, Marcelo; RESENDE, Marcelo. CBF remonta bancada da bola em Brasília. LANCE NET. Avaliable at: <http://blogs.lancenet.com.br/deprima/2012/05/23/cbf-remonta-bancada-da-bola-em-brasilia/> . Access on: 11 june 2014.

DESPORTO, COMISSÃO DE TURISMO E. CTD encerra semestre legislativo e apresenta balanço de suas atividades. Avaliable at: < http://www2.camara.leg.br/atividade-legislativa/comissoes/comissoes-permanentes/ctur/noticias/ctd-encerra-semestre-legislativo-e-apresenta-balanco-de-suas-atividades >. Access on: 12 Aug. 2014.

DOUSTI, Morteza et al. Sport policy in Iran. International Journal of Sport Policy and Politics, v. 5, n. 1, p. 151-158, 2013.

FERRI, Cristiano F. S. de; VALLE, Juliana Carla de F. Legislativo do Brasil. Brasília: Câmara dos Deputados, 2006.

FIGUEIREDO, Argelima C. Executivo e burocracia. In: MARTINS, Carlos B.; LESSA, Renato (Org.). Horizontes das ciências sociais no Brasil. São Paulo: Barcarolla, 2010. p. 191-216.

FRENTE PARLAMENTAR DA ATIVIDADE FÍSICA. Frente Parlamentar em defesa da atividade física para o desenvolvimento humano. Avaliable at: <www.fpdatividadefisica.com.br/wp/ > . Access on: 13 Aug. 2014.

GOMES, Fábio de B. C. Interações entre o Legislativo e o Executivo federal do Brasil na definição de políticas de interesse amplo: uma abordagem sistêmica, com aplicação na saúde. Brasília: Câmara dos Deputados, 2011.

GREEN, Mick; HOULIHAN, Barrie. Comparative elite sport development: sustems, structures and public policy. 1. ed. Oxford: Elsevier; Butterworth-Heinemann, 2008.

GUIMARÃES, Alexandre Sidnei. A bolsa-atleta eleva o desempenho de seus beneficiários? Análise do período 2005-2008. Brasília: Consultoria do Senado Federal, 2009. 
HALL, Peter A. Governing the economy: the politics of State intervention in Britain and France. Nova York: Oxford University Press, 1986.

HIRATA, Edson. A mercantilização do futebol e os subterrâneos da legislação esportiva brasileira (1980-2010). In: Simpósio Nacional de História - ANPUH, XXVI, 2011. Anais... São Paulo: Associação Nacional de História, 2011. p. 1-13.

IKENBERRY, G. John. Conclusion: an institutional approach to American foreign economic policy. International Organization, v. 42, n. 1, p. 219-243, 1988.

IPEA. O Conselho Nacional de Saúde na Visão de seus Conselheiros. Brasília: Instituto de Pesquisa Econômica Aplicada, 2012.

KRASNER, Stephen D. Approaches to the State: alternative conceptions and historical dynamics. Comparative Politics, v. 16, n. 2, p. 226-246, 1984.

LEÃO JÚNIOR, Fernando P. de S. Corporativismo e conflitos na gestão do futebol brasileiro. $M e$ diação, v. 5, n. 4, p. 31-51, 2004.

LINHALES, Meily A. A trajetória política do esporte no Brasil: interesses envolvidos, setores excluídos. Belo Horizonte: Universidade Federal de Minas Gerais, 1996.

LORENZO, Marina C. de. Análise das práticas de participação em conselhos deliberativos de política: o caso do Conselho Nacional do Esporte. Dissertação (mestrado) — Departamento de Administração, Universidade de Brasília, Brasília, 2008.

MANHÃES, Eduardo D. Política de esportes no Brasil. Rio de Janeiro: Paz e Terra, 2002.

MARINHO, Inezil P. História da educação física e dos desportos no Brasil. Brasília: Ministério da Educação e Saúde, 1952.

MARTINS, Luciano. Estado capitalista e burocracia no Brasil pós-64. Rio de Janeiro: Paz e Terra, 1985.

MENDES, Alessandra. Política pública de esporte: considerações sobre gestão, instituições políticas e método de pesquisa no Brasil. Revista Intercontinental de Gestão Desportiva, v. 3, n. Suplemento 1, p. 1-19, 2013.

MENDES, Alessandra; CODATO, Adriano. Institutional system of the State and public policy: the structure of sports management in Brazil. In: ANNUAL INTERNATIONAL CONFERENCE ON SPORTS: ECONOMIC, MANAGEMENT, MARKETING \& SOCIAL ASPECTS, 14 TH, Athens. p. 19-22.

MEZZADRI, Fernando M.; SILVA, Marcelo M. e. Desenvolvimento de um método para as pesquisas em políticas públicas de esporte no Brasil: uma abordagem de pesquisa mista. p. 15 31. In: MEZZADRI, Fernando M. (Org.). Políticas públicas e esporte. Várzea Paulista: Fontoura, 2014.

MINISTÉRIO DO ESPORTE. Ministério do Esporte. Avaliable at: <www.esporte.gov.br>. Access on: 2 Aug. 2012.

NORDLINGER, Eric A. et al. The return to the state: critiques. American Political Science Review, v. 82, n. 3, p. 875-901, 1988. 
O ESTADO DE SÃO PAULO. Em sua maioria, Bancada da Bola é reprovada nas urnas. 8 out. 2012. Avaliable at: <http://esportes.estadao.com.br/noticias/futebol,em-sua-maioria-bancada-da-bola-e-reprovada-nas-urnas,942507>. Access on: 11 June 2014.

PANEBIANCO, Angelo. Profissionalismo político e burocracia. In: PANEBIANCO, Angelo. Modelos de partido: organização e poder nos partidos políticos. São Paulo: Martins Fontes, 2005.

PARREIRA, Lêda Maria R. Frentes parlamentares: o caso da Frente Parlamentar de Apoio às Santas Casas de Misericórdia, Hospitais e Entidades Filantrópicas na Área de Saúde. Brasília: Câmara dos Deputados, 2012.

PETERS, B. Guy. El nuevo institucionalismo. La teoría institucional en ciencia política. Barcelona: Gedisa, 2003.

RASELLA, Davide et al. Effect of a conditional cash transfer programme on childhood mortality: a nationwide analysis of Brazilian municipalities. The Lancet, v. 382, n. 9.886, p. 57-64, 2013.

REBELLO, Aiuri; CRUZ, José. "Bancada da Bola" faz pressão e tira CBF de projeto sobre dívida dos times. Coluna UOL Esporte Futebol. Avaliable at: < http://esporte.uol.com.br/futebol/ultimas-noticias/2014/04/29/bancada-da-bola-faz-pressao-e-tira-cbf-de-projeto-sobre-divida-dos-times.htm > . Access on: 29 Apr. 2014.

RODRIGUES, Leôncio M. Partidos, ideologia e composição social: um estudo das bancadas partidárias na Câmara dos Deputados. Rio de Janeiro: Biblioteca Virtual de Ciências Humanas do Centro Edelstein de Pesquisas Sociais, 2009.

SENA, Viviane P. Frentes parlamentares proliferam no Legislativo. Portal do Departamento Intersindical de Assessoria Parlamentar. 4 jun. 2007. Avaliable at: <www.diap.org.br>. Access: 10 June 2014.

SENADO FEDERAL. Subcomissão Permanente do Esporte. Avaliable at: < http://legis.senado.leg.br/ comissoes/comissao?6\&codcol=728>. Access on: 13 Aug. 2014.

SILVA, Thiago M. da. A Bancada da Bola no Legislativo carioca: concepções, evidências e estratégias de uma representação singular. Rio de Janeiro: Fundação Getulio Vargas, 2013.

SILVA JR., Alexandre; FIGUEIREDO FILHO, Dalson B.; PARANHOS, Ranulfo. Quem controla o Legislativo? Paraná Eleitoral, v. 2, n. 2, p. 283-308, 2003.

SOUSA, Wilson Luiz L. de; SILVA, Régis Henrique dos R.; SILVA, Tiago O. da. O "estado da arte" em políticas públicas de esporte e lazer - 2007/2012. Brasília, 2013. Avaliable at: < http://cbce.tempsite. ws/congressos/index.php/conbrace2013/5conice/paper/view/5545/2472> . Access on: 13 Aug. 2014.

SOUZA, Pedro Herculano G. F. de; OSÓRIO, Rafael G. O perfil da pobreza no Brasil e suas mudanças entre 2003 e 2011. In: CAMPELLO, Tereza; NERI, Marcelo C. (Org.). Programa Bolsa Família: uma década de inclusão e cidadania. Brasilia: Ipea, 2013. p. 139-156.

STAREPRAVO, Fernando Augusto. Políticas públicas de esporte e lazer no Brasil: aproximações, intersecções, rupturas e distanciamentos entre os subcampos político/burocrático e científico/ acadêmico. Tese (doutorado) — Departamento de Educação Física, Universidade Federal do Paraná, Curitiba, 2011. 
STEINMO, Sven. The new institutionalism. In: CLARK, Paul B.; FOWERAKER, Joe (Org.). The encyclopedia of democratic thought. Londres: Routledge, 2001.

STEINMO, Sven et al. Structuring politics: historical institutionalism in comparative analysis. Cambridge: Cambridge University Press, 1992.

TUBINO, Manoel José G. O esporte no Brasil: do período colonial aos nossos dias. São Paulo: Ibrasa, 1996.

VERONEZ, Luiz Fernando C. Quando o Estado joga a favor do privado: as políticas de esporte após a Constituição federal de 1988. Tese (doutorado) — Faculdade de Educação Física, Universidade Estadual de Campinas, Campinas, 2005.

VIGNA, Edélcio. Bancada ruralista: o maior grupo de interesse no Congresso Nacional. Instituto de Estudos Socioeconômicos (Inesc), v. 7, n. 12, p. 1-16, 2007.

VIGNA, Edélcio. Bancada Ruralista: um grupo de interesse. Argumento - Instituto de Estudos Socioeconômicos (Inesc), n. 8, p. 1-52, 2001.

VOGEL, Luiz Henrique. As frentes parlamentares e a cultura política em defesa dos direitos humanos. Brasília: Câmara dos Deputados, 2005.

WOLF, Felipe. O comportamento dos deputados na Câmara Federal: uma abordagem de redes sociais. 2008.MSc (thesis) — Instituto de Ciência Política, Universidade de Brasília, Brasília, 2008.

Alessandra Mendes is a doctorate student in the Postgraduate Program of Public Policy at Federal University of Parana (UFPR) in Brazil. E-mail: alessandra.mendes@ifb.edu.br.

Adriano Codato is a professor of political science in the Department of Political Science and in the PostGraduate Program of Public Policy at Federal University of Parana (UFPR) in Brazil. E-mail: adriano@ ufpr.br. 